\title{
A High-Yield, Liquid-Phase Approach for the Partial Oxidation of Methane to Methanol using $\mathrm{SO}_{3}$ as the Oxidant
}

\author{
Sudip Mukhopadhyay, ${ }^{\mathrm{a}, \mathrm{b}, *}$ Mark Zerella, ${ }^{\mathrm{a}}$ Alexis T. Bell ${ }^{\mathrm{a}, *}$ \\ a Department of Chemical Engineering, University of California, Berkeley, CA 94720-1462, USA \\ Fax: (+1)-510-642-4778, e-mail: bell@cchem.berkeley.edu \\ b Present address: Honeywell International Inc., Buffalo, NY 14210, USA \\ Fax: (+1)-716-568-4451, e-mail: Sudip.Mukhopadhyay@honeywell.com
}

Received: December 27, 2004; Accepted: April 4, 2005

\begin{abstract}
A direct approach for producing methanol from methane in a three-step, liquid phase process is reported. In the first step, methane is reacted with $\mathrm{SO}_{3}$ to form methanesulfonic acid (MSA) at $75^{\circ} \mathrm{C}$ using a free-radical initiator and MSA as the solvent. Urea- $\mathrm{H}_{2} \mathrm{O}_{2}$ in combination with $\mathrm{RhCl}_{3}$ is found to be the most effective initiator $\left(57 \%\right.$ conversion of $\mathrm{SO}_{3}$; $7.2 \%$ conversion of $\mathrm{CH}_{4}$ ). MSA is then oxidized by $\mathrm{SO}_{3}$ at $160^{\circ} \mathrm{C}$ in a second step to produce a mixture containing methyl bisulfate and some methyl methanesulfonate ( $87 \%$ conversion of MSA). In the third step, the mixture of methyl bisulfate and methyl methanesulfonate is hydrolyzed in the presence of an organic solvent, to produce an organic phase containing methanol and an aqueous phase containing sulfuric acid and some MSA $63 \%$ conversion of methyl bisulfate; $72 \%$ conversion of methyl methanesulfonate). Overall, $58 \%$ of the MSA (of which $23 \%$ is derived from methane) is converted to methanol.
\end{abstract}

Keywords: catalytic oxidation; $\mathrm{C}-\mathrm{H}$ activation; methane; methanol; rhodium; sulfur trioxide

Attempts to carry out the partial oxidation of methane $\mathrm{e}^{[1-12]}$ to methanol in the gas phase have met with limited success because of difficulties in controlling the free radical processes that are involved. Since methanol is more reactive than methane, the formation of $\mathrm{CO}$ and $\mathrm{CO}_{2}$ via secondary combustion is unavoidable. While a variety of catalysts, mostly metal oxides, have been reported for the partial oxidation of methane to methanol, all require high temperatures and the reported methanol yields based on methane have generally been less than $10 \%$.

An indirect approach for the conversion of methane to methanol has been reported by Periana et al. ${ }^{[13-16]}$ These authors have demonstrated that methane can be converted to methyl bisulfate in a single-step using $\mathrm{Hg}^{2+}$, Pt-complexes, or $\mathrm{I}_{2}^{+}$as catalysts. The reaction is carried out in fuming sulfuric acid at temperatures of $180-220^{\circ} \mathrm{C}$, and bisulfate yields of up to $43 \%$ based on methane can be achieved. Since methyl bisulfate cannot be readily separated from sulfuric acid, it is hydrolyzed to methanol by addition of water to the methyl bisulfate-sulfuric acid solution. Separation of methanol from the resulting solution is difficult, and the dilute sulfuric acid solution remaining must be concentrated before it can be recycled. Here, we show that pure methanol can be produced from methane and $\mathrm{SO}_{3}$ in a threestep process that avoids the use of sulfuric acid as a solvent and enables the facile separation of methanol. Concentrated sulfuric acid is produced as a by-product, which can either be sold or reprocessed to elemental sulfur.

$$
\begin{aligned}
& \mathrm{CH}_{4}+\mathrm{SO}_{3} \underset{\substack{\mathrm{CH}_{3} \mathrm{SO}_{3} \mathrm{H} \\
75^{\circ} \mathrm{C}, 6 \mathrm{~h}}}{\stackrel{\text { Initiator }}{\longrightarrow}} \mathrm{CH}_{3} \mathrm{SO}_{3} \mathrm{H} \underset{160^{\circ} \mathrm{C}, 10 \mathrm{~h}}{\stackrel{\mathrm{SO}_{3}}{\Rightarrow}} \mathrm{CH}_{3} \times \underset{\mathrm{C}_{2} \mathrm{H}_{4} \mathrm{Cl}_{2}}{\stackrel{\text { Water }}{\Rightarrow}} \mathrm{CH}_{3} \mathrm{OH} \\
& \text { Where, } \mathrm{X}=-\mathrm{OSO}_{3} \mathrm{H},-\mathrm{SO}_{3} \mathrm{CH}_{3}
\end{aligned}
$$

In a typical reaction, methanesulfonic acid (MSA) is formed in a high-pressure, glass-lined autoclave by reacting ${ }^{13} \mathrm{CH}_{4}$ with $\mathrm{SO}_{3}$ dissolved in $\mathrm{CH}_{3} \mathrm{SO}_{3} \mathrm{H}$ containing a free radical initiator. ${ }^{[17-22]}$ Reactions are carried out for $6 \mathrm{~h}$ at $75^{\circ} \mathrm{C} . \mathrm{CH}_{3} \mathrm{SO}_{3} \mathrm{H}$ is then oxidized in the presence of a catalyst to $\mathrm{CH}_{3} \mathrm{OSO}_{3} \mathrm{H}$ and $\mathrm{CH}_{3} \mathrm{SO}_{3} \mathrm{CH}_{3}$ by reaction with $\mathrm{SO}_{3}$ at temperatures of $130-185^{\circ} \mathrm{C}$. Products are identified and quantified by ${ }^{1} \mathrm{H}$ and ${ }^{13} \mathrm{C}$ NMR spectroscopy. In the last step, $\mathrm{CH}_{3} \mathrm{OSO}_{3} \mathrm{H}$ is hydrolyzed in the presence of an organic solvent. The methanol is then distilled from the organic phase and identified by NMR, GC-MS, and Raman spectroscopy.

Table 1 shows the effects of initiator composition on the sulfonation of methane to MSA with $\mathrm{SO}_{3}$ at $75^{\circ} \mathrm{C}$. Conversions are expressed in terms of $\mathrm{SO}_{3}$ since it is the limiting reagent and $\mathrm{CH}_{4}$ is present in excess. $\mathrm{K}_{4} \mathrm{P}_{2} \mathrm{O}_{8}$ is the least effective initiator, whereas $\mathrm{K}_{2} \mathrm{~S}_{2} \mathrm{O}_{8}$, urea- $\mathrm{H}_{2} \mathrm{O}_{2}$, and $\mathrm{CaO}_{2}$ are moderately effective. However, urea- $\mathrm{H}_{2} \mathrm{O}_{2}$ in combination with $\mathrm{RhCl}_{3}$ is the most effective initiator, enabling $57 \%$ of the $\mathrm{SO}_{3}$ to be converted to MSA using MSA as the solvent. Previous studies 
Table 1. Effect of initiator composition on the yield of methanesulfonic acid (MSA). ${ }^{[a]}$

\begin{tabular}{lllll}
\hline$\#$ & Initiator [mmol] & $\begin{array}{l}\text { MSA produced, } \\
{[\mathrm{mmol}]}\end{array}$ & $\begin{array}{l}\text { \% Conversion of } \\
\mathrm{SO}_{3} \text { to } \mathrm{MSA}\end{array}$ & $\begin{array}{l}\text { Volumetric productivities to MSA } \\
{\left[\mathrm{mol} \mathrm{cm}^{-3} \mathrm{~s}^{-1}\right]}\end{array}$ \\
\hline 1 & $\mathrm{~K}_{2} \mathrm{~S}_{2} \mathrm{O}_{8}, 0.07$ & 5 & 24 & $7.71 \times 10^{-8}$ \\
2 & $\mathrm{~K}_{4} \mathrm{P}_{2} \mathrm{O}_{8}, 0.07$ & 3 & 14 & $4.62 \times 10^{-8}$ \\
3 & $\mathrm{CaO}_{2}, 0.09$ & 9 & 43 & $1.38 \times 10^{-7}$ \\
4 & $\mathrm{Urea}_{2} \mathrm{H}_{2}, 0.4$ & 7 & 33 & $1.05 \times 10^{-7}$ \\
5 & $\mathrm{Urea}_{2} \mathrm{H}_{2}, 0.4 / \mathrm{RhCl}_{3}, 0.1$ & 12 & 57 & $1.85 \times 10^{-7}$ \\
\hline
\end{tabular}

[a] Reaction conditions: ${ }^{13} \mathrm{CH}_{4}, 600 \mathrm{psig}(166 \mathrm{mmol})$; $\mathrm{SO}_{3}, 21 \mathrm{mmol}$; MSA, $3.96 \mathrm{~g}$; time, $6 \mathrm{~h}$; temperature, $75^{\circ} \mathrm{C}$.

Table 2. $\mathrm{RhCl}_{3}$-catalyzed oxidation of MSA by $\mathrm{SO}_{3}$ to methyl bisulfate. ${ }^{[\mathrm{a}]}$

\begin{tabular}{|c|c|c|c|c|c|c|c|}
\hline \# & $T\left[{ }^{\circ} \mathrm{C}\right]$ & $\begin{array}{l}\text { Oxidant } \\
\text { [mmol] }\end{array}$ & $\begin{array}{l}\% \text { Conversion of } \\
\text { MSA [mmol] }\end{array}$ & $\begin{array}{l}\% \text { Conversion } \\
\text { of MSA to } \\
\mathrm{CH}_{3} \mathrm{OSO}_{3} \mathrm{H} \\
{[\mathrm{mmol}]}\end{array}$ & $\begin{array}{l}\% \text { Conversion } \\
\text { of MSA to } \\
\mathrm{CH}_{3} \mathrm{SO}_{3} \mathrm{CH}_{3} \\
{[\mathrm{mmol}]}\end{array}$ & $\begin{array}{l}\text { \% Selectivity } \\
\text { to } \mathrm{CH}_{3} \mathrm{X}^{[\mathrm{b}]}\end{array}$ & $\begin{array}{l}\text { Mol of } \\
\mathrm{CH}_{3} \mathrm{X}^{[\mathrm{b}]} \mathrm{cm}^{-3} \mathrm{~s}^{-1}\end{array}$ \\
\hline 1 & 130 & $\mathrm{SO}_{3}, 15$ & $8(4.2)$ & $8(4.2)$ & $0(0)$ & 100 & $2.92 \times 10^{-8}$ \\
\hline 2 & 150 & $\mathrm{SO}_{3}, 15$ & $12(6.3)$ & $9(5)$ & $3(0.7)$ & 100 & $3.96 \times 10^{-8}$ \\
\hline 3 & 160 & $\mathrm{SO}_{3}, 15$ & $15(8)$ & $10(5.5)$ & $4(1.0)$ & 94 & $4.51 \times 10^{-8}$ \\
\hline $4^{c}$ & 185 & $\mathrm{SO}_{3}, 15$ & $18(9.5)$ & $4(2)$ & $11(3.0)$ & 84 & $2.31 \times 10^{-8}$ \\
\hline 4 & 160 & $\mathrm{SO}_{3}, 21$ & $33(17.5)$ & $26(14)$ & $5(1.2)$ & 93 & $1.05 \times 10^{-7}$ \\
\hline 5 & 160 & $\mathrm{SO}_{3}, 30$ & $48(25.4)$ & $30(16)$ & $15(4.0)$ & 94 & $1.38 \times 10^{-7}$ \\
\hline 6 & 160 & $\mathrm{SO}_{3}, 55$ & $88(47)$ & 55 (29) & $28(7.5)$ & 93 & $2.53 \times 10^{-7}$ \\
\hline 7 & 160 & $\mathrm{SO}_{3}, 64$ & $100(53)$ & $49(26)$ & 38 (10) & 87 & $2.50 \times 10^{-7}$ \\
\hline $8^{\mathrm{d}}$ & 120 & $\mathrm{H}_{2} \mathrm{O}_{2}, 30$ & $0(0)$ & $0(0)$ & $0(0)$ & 0 & 0 \\
\hline 9 & 160 & $\mathrm{O}_{2}, 33$ & $2(1)$ & $2(1)$ & - & 50 & $6.94 \times 10^{-9}$ \\
\hline $10^{\mathrm{e}}$ & 160 & $\mathrm{SO}_{3}, 65$ & $100(53)$ & $96(51)$ & $0(0)$ & 96 & $5.9 \times 10^{-7}$ \\
\hline
\end{tabular}

[a] Reaction conditions: MSA, $5.11 \mathrm{~g},(53 \mathrm{mmol})$; $\mathrm{T}, 160^{\circ} \mathrm{C}$; time, $10 \mathrm{~h} . \mathrm{RhCl}_{3}, 0.1 \mathrm{mmol}$.

${ }^{[b]} \mathrm{CH}_{3} \mathrm{X}$ is methanol equivalent $\left(\mathrm{CH}_{3} \mathrm{OSO}_{3} \mathrm{H}\right.$ and $\left.\mathrm{CH}_{3} \mathrm{SO}_{3} \mathrm{CH}_{3}\right)$.

[c] $15 \mathrm{~h}$.

[d] $6 \mathrm{~h}$.

[e] $\mathrm{H}_{2} \mathrm{SO}_{4}$ is the solvent.

utilizing the initiators listed in Table 1 have shown that $75^{\circ} \mathrm{C}$ is an optimal temperature, since at higher temperatures the initiator rapidly decomposes, producing $\mathrm{O}_{2}{ }^{\left[{ }^{[2]}\right.}$ Since the reaction is thought to occur via a free radical mechanism, ${ }^{[1-22]}$ the presence of $\mathrm{O}_{2}$ inhibits the sulfonation of methane to MSA. Thus, for example, sulfonation at $160{ }^{\circ} \mathrm{C}$ in fuming sulfuric acid results in a $4 \%$ conversion of $\mathrm{SO}_{3}$ to $\mathrm{CH}_{3} \mathrm{OSO}_{3} \mathrm{H}$ after $6 \mathrm{~h}$ of reaction, but no formation of MSA.

Table 2 shows the effects of different reaction conditions on the oxidation of MSA to $\mathrm{CH}_{3} \mathrm{X}\left(\mathrm{CH}_{3} \mathrm{OSO}_{3} \mathrm{H}\right.$ or $\mathrm{CH}_{3} \mathrm{SO}_{3} \mathrm{CH}_{3}$ ) by $\mathrm{SO}_{3}$. When a mixture containing $15 \mathrm{mmol}$ of $\mathrm{SO}_{3}$ and $53 \mathrm{mmol} \mathrm{MSA}$ was heated at $130{ }^{\circ} \mathrm{C}$ for $10 \mathrm{~h}, 8 \%$ of the MSA charged into the reactor was transformed to $\mathrm{CH}_{3} \mathrm{OSO}_{3} \mathrm{H}$ with $100 \%$ selectivity (Figure 1a). Increasing the temperature to $150{ }^{\circ} \mathrm{C}$ raised the conversion of MSA to $\mathrm{CH}_{3} \mathrm{X}$ to $12 \%$, of which $75 \%$ was $\mathrm{CH}_{3} \mathrm{OSO}_{3} \mathrm{H}$ and $25 \%$ was $\mathrm{CH}_{3} \mathrm{SO}_{3} \mathrm{CH}_{3}$. At $160{ }^{\circ} \mathrm{C}, 15 \%$ of the MSA was converted to products, of these products $94 \%$ appeared as $\mathrm{CH}_{3} \mathrm{X}$ and the balance as a mixture of $\mathrm{CH}_{3} \mathrm{OSO}_{2} \mathrm{OCH}_{3}, \mathrm{CH}_{2}\left(\mathrm{SO}_{3} \mathrm{H}\right)_{2}$, and $\mathrm{CH}_{3}\left(\mathrm{SO}_{3}\right)_{\mathrm{n}} \mathrm{H}$. While $\mathrm{CH}_{3} \mathrm{OSO}_{3} \mathrm{H}$ remained as the major

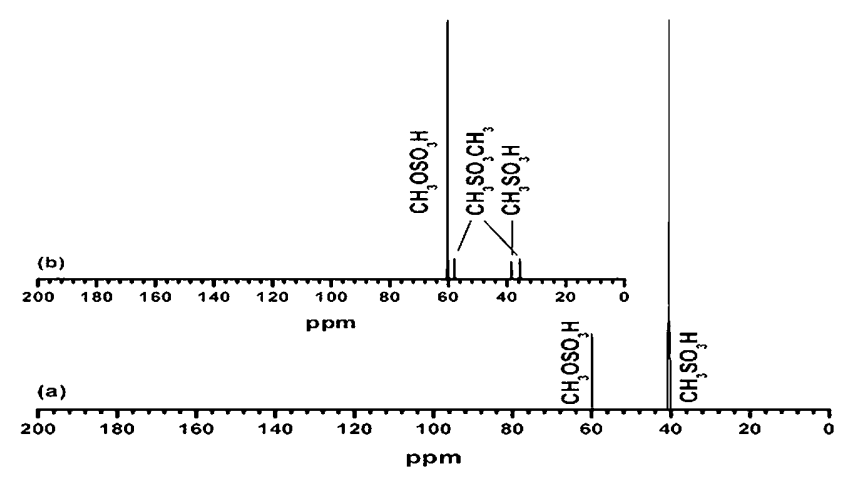

Figure 1. (a) ${ }^{13} \mathrm{C}$ NMR of the mixture after $10 \mathrm{~h}$ of reaction between MSA and $\mathrm{SO}_{3}, T=130{ }^{\circ} \mathrm{C}$; $\mathrm{SO}_{3}, 15 \mathrm{mmol}$. (b) ${ }^{13} \mathrm{C}$ NMR of the mixture after $10 \mathrm{~h}$ of reaction between MSA with $\mathrm{SO}_{3}, T=160{ }^{\circ} \mathrm{C} ; \mathrm{SO}_{3}, 55 \mathrm{mmol}$.

product at $160^{\circ} \mathrm{C}$ (Figure $1 \mathrm{~b}$ ), $\mathrm{CH}_{3} \mathrm{SO}_{3} \mathrm{CH}_{3}$ became the major product when the reaction temperature was raised to $185^{\circ} \mathrm{C}$.

The effect of the amount of $\mathrm{SO}_{3}$ on the oxidation of MSA to $\mathrm{CH}_{3} \mathrm{X}$ was also studied. Raising the amount of 
Table 3. Single-pass extractive hydrolysis of $\mathrm{CH}_{3} \mathrm{OSO}_{3} \mathrm{H}$ to $\mathrm{CH}_{3} \mathrm{OH}$ in a solvent.

\begin{tabular}{|c|c|c|c|c|c|}
\hline$\#$ & $\begin{array}{l}\text { Mol ratio of } \\
\mathrm{H}_{2} \mathrm{O} / \mathrm{CH}_{3} \mathrm{OSO}_{3} \mathrm{H}\end{array}$ & Solvent & $T\left[{ }^{\circ} \mathrm{C}\right]$ & $\begin{array}{l}\text { Percent of } \mathrm{MeOH} \text { extracted } \\
\text { into the solvent phase }[\mathrm{mol} \%]\end{array}$ & $\begin{array}{l}\mathrm{H}_{2} \mathrm{SO}_{4} \text { in the aqueous phase } \\
\text { [wt \%] }\end{array}$ \\
\hline 1 & 1 & $\mathrm{CH}_{2} \mathrm{Cl}_{2}$ & 25 & 6 & 87 \\
\hline 2 & 3 & $\mathrm{CH}_{2} \mathrm{Cl}_{2}$ & 25 & 17 & 65 \\
\hline 3 & 5 & $\mathrm{CH}_{2} \mathrm{Cl}_{2}$ & 25 & 29 & 54 \\
\hline 4 & 7 & $\mathrm{CH}_{2} \mathrm{Cl}_{2}$ & 25 & 32 & 44 \\
\hline 5 & 10 & $\mathrm{CH}_{2} \mathrm{Cl}_{2}$ & 25 & 39 & 36 \\
\hline 6 & 5 & $\mathrm{CH}_{2} \mathrm{Cl}_{2}$ & 40 & 46 & 54 \\
\hline 7 & 5 & $\mathrm{CHCl}_{3}$ & 61 & 62 & 54 \\
\hline $8^{\mathrm{b}}$ & 5 & $\mathrm{CHCl}_{3}$ & 61 & 58 & 49 \\
\hline $9^{c}$ & 5 & $\mathrm{CHCl}_{3}$ & 61 & 53 & 45 \\
\hline $10^{\mathrm{d}}$ & 5 & $\mathrm{CHCl}_{3}$ & 61 & 61 & 54 \\
\hline $11^{\mathrm{e}}$ & 5 & $\mathrm{CHCl}_{3}$ & 61 & 53 & 54 \\
\hline 12 & 5 & $\mathrm{C}_{2} \mathrm{H}_{4} \mathrm{Cl}_{2}$ & 83 & 63 & 54 \\
\hline $13^{\mathrm{f}}$ & 5 & $\mathrm{C}_{2} \mathrm{H}_{4} \mathrm{Cl}_{2}$ & 83 & 72 & - \\
\hline
\end{tabular}

$\mathrm{SO}_{3}$ added to the reaction mixture from 15 to $64 \mathrm{mmol}$ increased the conversion of MSA from $15 \%$ to $100 \%$. While the selectivity to $\mathrm{CH}_{3} \mathrm{X}$ was independent of the amount of $\mathrm{SO}_{3}$, the distribution between $\mathrm{CH}_{3} \mathrm{OSO}_{3} \mathrm{H}$ and $\mathrm{CH}_{3} \mathrm{SO}_{3} \mathrm{CH}_{3}$ shifted from $85 \% \mathrm{CH}_{3} \mathrm{OSO}_{3} \mathrm{H}$ to $72 \%$.

MSA oxidation by $\mathrm{H}_{2} \mathrm{O}_{2}, \mathrm{O}_{2}$, and $\mathrm{H}_{2} \mathrm{SO}_{4}$ was also considered. $\mathrm{H}_{2} \mathrm{O}_{2}$ was inactive at $130^{\circ} \mathrm{C}$ and only a small amount of $\mathrm{CH}_{3} \mathrm{OSO}_{3} \mathrm{H}$ was observed when $\mathrm{O}_{2}$ was used as the oxidant. A $12 \%$ conversion of MSA to $\mathrm{CH}_{3} \mathrm{OSO}_{3} \mathrm{H}$ was achieved at $160^{\circ} \mathrm{C}$ after $10 \mathrm{~h}$ of reaction in $100 \% \mathrm{H}_{2} \mathrm{SO}_{4}$ and no $\mathrm{CH}_{3} \mathrm{SO}_{3} \mathrm{CH}_{3}$ was observed. When $\mathrm{H}_{2} \mathrm{SO}_{4}$ was used as the solvent and $\mathrm{SO}_{3}$ as the oxidant, $96 \%$ of the initial MSA charged into the reactor was converted to $\mathrm{CH}_{3} \mathrm{OSO}_{3} \mathrm{H}$ and, again, no $\mathrm{CH}_{3} \mathrm{SO}_{3} \mathrm{CH}_{3}$ was observed.

Table 3 shows the effectiveness of the single-pass extractive hydrolysis of $\mathrm{CH}_{3} \mathrm{OSO}_{3} \mathrm{H}$ in the presence of a water immiscible organic solvent. Low boiling halogenated solvents such as $\mathrm{CH}_{2} \mathrm{Cl}_{2}, \mathrm{CHCl}_{3}$, and $\mathrm{C}_{2} \mathrm{H}_{4} \mathrm{Cl}_{2}$ were used. For a fixed set of hydrolysis and extraction conditions, $\mathrm{CHCl}_{3}$ and $\mathrm{C}_{2} \mathrm{H}_{4} \mathrm{Cl}_{2}$ showed comparable effectiveness, and both solvents were superior to $\mathrm{CH}_{2} \mathrm{Cl}_{2}$. Since the extent of $\mathrm{CH}_{3} \mathrm{OSO}_{3} \mathrm{H}$ hydrolysis depends on the molar ratio of $\mathrm{H}_{2} \mathrm{O} / \mathrm{CH}_{3} \mathrm{OSO}_{3} \mathrm{H}$, the value of this ratio was varied. Table 3 shows that as the ratio increases from 1 to 10 , the percent extraction of $\mathrm{CH}_{3} \mathrm{OH}$ increases rapidly at first but then more slowly. At the same time, the weight percent of $\mathrm{H}_{2} \mathrm{SO}_{4}$ in the aqueous phase decreases monotonically. A molar ratio of 5 to $1 \mathrm{H}_{2} \mathrm{O}$ to $\mathrm{CH}_{3} \mathrm{OSO}_{3} \mathrm{H}$ resulted in a $29 \%$ extraction of methanol in one step and an aqueous phase containing $54 \mathrm{wt} \% \mathrm{H}_{2} \mathrm{SO}_{4}$. To determine the effect of MSA on the extraction of metha- nol, experiments were performed in which 10 and $20 \%$ MSA was present in the feed. The extraction efficiency decreased by a small amount as the amount of MSA increased. Reducing the ratio of organic solvent to $\mathrm{CH}_{3} \mathrm{OSO}_{3} \mathrm{H}$ from 20 to 13 had little effect on the methanol extraction efficiency; however, decreasing this ratio to $10 \mathrm{had}$ a noticeable detrimental effect. The hydrolysis of $\mathrm{CH}_{3} \mathrm{SO}_{3} \mathrm{CH}_{3}$ to $\mathrm{CH}_{3} \mathrm{OH}$ was carried out under conditions identical to those used for $\mathrm{CH}_{3} \mathrm{OSO}_{3} \mathrm{H}$ (entry 12 in Table 3). A methanol extraction of $72 \%$ could be achieved starting from $\mathrm{CH}_{3} \mathrm{SO}_{3} \mathrm{CH}_{3}$, as apposed to $63 \%$ in the case of $\mathrm{CH}_{3} \mathrm{OSO}_{3} \mathrm{H}$.

As seen in Table 3, the final sulfuric acid concentration in the aqueous phase remained close to $60 \mathrm{wt} \%$. This level is sufficiently high for direct use in the dyes, paint, and pharmaceutical industries. $100 \% \quad \mathrm{H}_{2} \mathrm{SO}_{4}$ could be produced by solar concentration or by addition of $\mathrm{SO}_{3}$.

To confirm the formation of methanol as the final product, the extract obtained using $\mathrm{ClCH}_{2} \mathrm{CH}_{2} \mathrm{Cl}$ was fractionated. The product that was condensed was identified as pure methanol on the basis of ${ }^{13} \mathrm{C}$ NMR (49 ppm) and Raman spectroscopy $(1039,1459,2840$, 2949 , and $3341 \mathrm{~cm}^{-1}$ ).

In conclusion, we have demonstrated a high-yield approach for the selective conversion of methane to methanol. The proposed scheme could readily be incorporated into a refinery, since the $\mathrm{SO}_{3}$ required for the process could be produced by oxidation of $\mathrm{H}_{2} \mathrm{~S}$, the product of petroleum hydrodesulfurization. ${ }^{[23-26]}$ The $\mathrm{SO}_{2}$ formed during the oxidation of MSA can be recovered readily and reoxidized to $\mathrm{SO}_{3}$. The concentrated sulfuric acid 
produced as a by-product of $\mathrm{CH}_{3} \mathrm{OSO}_{3} \mathrm{H}$ hydrolysis could be sent to the Claus process where it would react with $\mathrm{H}_{2} \mathrm{~S}$ to produce elemental sulfur which would finally be transformed to $\mathrm{SO}_{3}$ by catalytic oxidation with air.

\section{Experimental Section}

\section{Typical Procedure}

In a typical reaction, a 100-mL, glass-lined, high-pressure Parr autoclave reactor was charged with $0.4 \mathrm{mmol}$ of urea- $\mathrm{H}_{2} \mathrm{O}_{2}$, $0.1 \mathrm{mmol}$ of $\mathrm{RhCl}_{3}, 3.76 \mathrm{~g}$ of MSA, and $21 \mathrm{mmol}$ of $\mathrm{SO}_{3}$. A small Teflon-coated magnetic stir bar was used to stir the reaction mixture. The reactor was purged with $\mathrm{N}_{2}$ to expel the air and pressurized with 600 psig of ${ }^{13} \mathrm{CH}_{4}$. The reactor was then heated to $75^{\circ} \mathrm{C}$ under stirring and kept at that temperature for $6 \mathrm{~h}$. After the stipulated period of time, the reactor was cooled, purged with $\mathrm{N}_{2}$, and opened to add extra $\mathrm{SO}_{3}$ to the reaction mixture. The autoclave was then closed, purged with $\mathrm{N}_{2}$ and then pressurized with 300 psig of $\mathrm{N}_{2}$ gas and heated slowly to $160^{\circ} \mathrm{C}$. The reaction mixture was stirred at $160^{\circ} \mathrm{C}$ for $10 \mathrm{~h}$. After this period, the reactor was cooled, the pressure was released, and the reactor was purged with $\mathrm{N}_{2}$ gas. The reaction mixture was analyzed ${ }^{1} \mathrm{H}$ and ${ }^{13} \mathrm{C}$ NMR. $\mathrm{D}_{2} \mathrm{O}$ was used in a capillary as the lock reference. The ${ }^{1} \mathrm{H}$ NMR chemical shift was $2.87 \mathrm{ppm}$ to $3.04 \mathrm{ppm}$ for MSA, $3.76 \mathrm{ppm}$ to $3.98 \mathrm{ppm}$ for $\mathrm{CH}_{3} \mathrm{OSO}_{3} \mathrm{H}, 3.13 \mathrm{ppm}$ and $3.83 \mathrm{ppm}$ for $\mathrm{CH}_{3} \mathrm{SO}_{3} \mathrm{CH}_{3}$, the range of chemical shifts in each case depending on the product concentration. A ${ }^{1} \mathrm{H}$ NMR chemical shift of $3.27 \mathrm{ppm}$ was observed for $\mathrm{CH}_{3} \mathrm{OH}$. The corresponding ${ }^{13} \mathrm{C}$ NMR chemical shifts are: $39.5-40.5 \mathrm{ppm}$ for MSA, 60-60.5 ppm for $\mathrm{CH}_{3} \mathrm{OSO}_{3} \mathrm{H}$, and $35.5-36.0 \mathrm{ppm}$ and $58.0-58.5 \mathrm{ppm}$ for $\mathrm{CH}_{3} \mathrm{SO}_{3} \mathrm{CH}_{3}$.

\section{Acknowledgements}

This work was supported by a grant from BP as a part of the Methane Conversion Cooperative.

\section{References}

[1] C. L. Hill, Activation and Functionalization of Alkanes, Wiley, New York, 1989.

[2] M. G. Axelrod, A. M. Gaffney, R. Pitchai, J. A. Sofranko, Natural Gas Conversion II, Elsevier, Amsterdam, 1994.

[3] A. E. Shilov, G. B. Shul'pin, Activation and Catalytic Reactions of Saturated Hydrocarbons in the Presence of
Metal Complexes, Kluwer Academic Publishers, Dordrecht, 2000.

[4] a) G. A. Olah, A. Molnar, Hydrocarbon Chemistry, Wiley, New York, 1995; b) M. Lin, A. Sen, Nature 1994, $368,613-615$.

[5] H. D. Gesser, N. R. Hunter, Catal. Today 1998, 42, $183-$ 189.

[6] J. H. Lunsford, Catal. Today 2000, 63, 165-174.

[7] K. Otsuka, Y. Wang, Appl. Catal. A: Gen. 2001, 222, $145-161$.

[8] S. Mukhopadhyay, A. T. Bell, Chem. Commun. 2003, 1590-1591.

[9] M. Zerella, S. Mukhopadhyay, A. T. Bell, Org. Lett. 2003, 5, 3193-3196.

[10] G. A. Foulds, B. F. Gray, Fuel Proc. Tech. 1995, 42, 12950.

[11] J. A. Labinger, J. E. Bercaw, Nature 2002, 417, 507.

[12] S. Mukhopadhyay, A. T. Bell, J. Mol. Catal. A: Chem. 2004, 211, 59-65.

[13] R. A. Periana, D. J. Taube, E. R. Evitt, D. G. Loffer, P. R. Wentrcek, G. Voss, T. A. Masuda, Science 1993, 259, 340-343.

[14] R. A. Periana, D. J. Taube, S. Gamble, H. Taube, T. Satoh, H. Fujii, Science 1998, 280, 560-564.

[15] R. A. Periana, O. Mironov, D. J. Taube, S. Gamble, Chem. Commun. 2002, 2376-2377.

[16] R. A. Periana, G. Bhalla, W. J. Tenn, III, K. J. H. Young, X. Y. Liu, O. Mironov, C. J. Jones, V. R. Ziatdinov, J. Mol. Catal. A: Chem. 2004, 220, 7-25.

[17] N. Basickes, T. E. Hogan, A. Sen, J. Am. Chem. Soc. 1996, 118, 13111-13112.

[18] M. Asadullah, T. Kitamura, Y. Fujiwara, Angew. Chem. Int. Ed. 2000, 39, 2475-2478.

[19] S. Mukhopadhyay, A. T. Bell, Ind. Eng. Chem. Res. 2002, 41, 5901-5905.

[20] S. Mukhopadhyay, A. T. Bell, Angew. Chem. Int. Ed. 2003, 42, 1019-1021.

[21] S. Mukhopadhyay, A. T. Bell, J. Am. Chem. Soc. 2003, 125, 4406-4407.

[22] S. Mukhopadhyay, A. T. Bell, Angew. Chem. Int. Ed. 2003, 42, 2990-2993.

[23] R. H. Hass, J. W. Ward, US Patent 4,444,742, 1982.

[24] J. Z. Zhang, F. J. Millero, Geochimica Acta 1993, 57, $1708-1718$.

[25] P. Schoubye, European Patent 852,159, 1998.

[26] Y. V. Filatov, V. V. Igin, L. M. Varshavskaya, A. A. Ryzhkova, Zh. Prik. Khimii 1988, 61, 1226-1231. 